\title{
13
}

\section{Bridging the Belt and Road Initiative in Papua New Guinea}

\author{
Sarah O'Dowd
}

The decision by Papua New Guinea (PNG) to sign on to China's ambitious Belt and Road Initiative (BRI) has reignited concerns regarding the intentions, impacts and long-term sustainability of Chinese financial activities in the Pacific. As one of the first Pacific nations to sign on to the BRI, PNG's decision is a manifestation of increasing engagement with China by Pacific Island countries (PICs). China's relations with PICs were recently scrutinised over allegations that China planned to build a military base in Vanuatu, which was denied by both countries. Though some traditional donors to the Pacific, like Australia, suspect that Beijing aims to become the dominant power in the region, these concerns are likely influenced by Australia's own intentions to incorporate the Pacific within the 'rules-based global order' (Australian Government 2017). Research and media reports on the BRI tend to be dominated by this 'China threat' discourse that envisions the BRI as a monolithic, centralised and primarily strategic policy that exploits partner countries to enable Chinese access to foreign natural resources, markets and critical infrastructure. Some studies, such as the widely cited report by Harvard University researchers, extend this narrative by arguing that unsustainable loans associated with Chinese-funded infrastructure projects render certain PICs vulnerable to Beijing's influence (Kehoe 2018). Through this zero-sum lens, PICs are often envisioned as the passive victims of China's exploitation. 
Despite the significant academic and political interest in the BRI's varied impacts, this narrative is rarely interrogated. This focus may lead to scholars overlooking the reasons PICs sometimes select Chinese financing over other sources and the multifaceted nature of Chinese investing entities and projects. Furthermore, the 'debt-trap diplomacy' narrative tends to divert attention away from the more nuanced, and often more immediate, risks that joining the BRI may pose to PNG's environment and governance. These risks may not be due to the Chinese nature of investment, but rather to the inexperienced or unethical character of certain companies, which may be paralleled by similarly damaging behaviour by firms from other nations. While certain Chinese projects in the Pacific do generate negative results for PICs, treating all Chinese financial activities the same may lead to an overly assertive response from countries like Australia that see China as interfering in Canberra's 'backyard' (Wallis 2012). As PNG's involvement in the BRI is likely to intensify these assumptions and the fears that China will entrap PNG in unsustainable debt, this chapter seeks to explore the credibility of popular narratives surrounding the BRI and determine the likely impacts of the BRI in PNG, as well as traditional donors' responses. Though development is a contested concept and aid to the Pacific is increasingly securitised, this chapter attempts to provide an objective view of the likely opportunities and risks PNG faces when engaging in the BRI. Similarly, while the China-PNG relationship is considered in this chapter, it should be noted that the actions of other regional actors, such as Australia, may deliver similarly mixed outcomes for PNG.

This chapter is divided into three sections that each assess one broad perceived risk the BRI presents to PNG: the 'debt-trap diplomacy' theory, the BRI's socioeconomic impacts and the influence of Chinese financing on governance. The first section introduces the BRI and 'debttrap diplomacy'. It then investigates PNG's current debt situation, the likelihood that the BRI in PNG is a coherent foreign policy manoeuvre by Beijing that aims to erode the influence of traditional regional powers, and the potential threats that Chinese investment poses to PNG's sovereignty. This section argues that Chinese financing in the Pacific is fragmented, which may reduce the likelihood that these funds are part of a deliberate strategic ploy by China to exploit PICs. Nonetheless, PNG's indebtedness does present an economic risk if Port Moresby's revenue crisis continues and the country refrains from adopting fiscal consolidation policies (Pryke 2017). Similarly, a continuation of China's current lending practices, particularly the US $\$ 4.1$ billion financing for the promised BRI roads project, could imperil PNG's debt sustainability (Rajah et al. 2019). 
The second section evaluates the BRI's impact on PNG's economy and environment to argue that PNG and China's current policy frameworks may be unable to ensure that BRI projects are conducted legally, sustainably and with the consent of relevant local stakeholders and landowners. Failure to meet these criteria will reduce the development benefits that accrue to locals. This may spark local protests that are able to delay and, in some cases, even stop foreign investment projects. Using data from the American Enterprise Institute's China Global Investment Tracker, this section argues that large-scale Chinese investments in PNG tend to be concentrated in resource-intensive, extractive and polluting industries. This investment history, coupled with concerns that the BRI may 'lock-in' poor environmental practices in developing nations, raises particular concerns for island states like PNG (Hong and Johnson 2018).

The final section investigates the impact of Chinese financing on governance in PNG and finds that while certain Chinese companies abide by international norms to the extent of winning lucrative contracts from international lending bodies like the Asian Development Bank (ADB), others may engage in corrupt practices that harm governance in PNG. However, this corruption is often believed to be facilitated by PNG partners. This indicates that it is not purely the presence of Chinese investment that harms governance in PNG, but rather the combination of corrupt Chinese and PNG entities, which may complicate reform attempts in PNG. The reaction to PNG's decision to join the BRI by traditional donors like Australia is also considered. The extent to which PNG's decision to join the BRI alters the current regional dynamics may depend on PNG's ability and willingness to exploit Australia and China's competition to access higherquality or more lucrative financing arrangements.

\section{The BRI in PNG: A debt trap or development opportunity?}

\section{An overview of the BRI in PNG}

Under President Xi Jinping's leadership, China's international engagement has come to be defined by the US $\$ 1$ trillion BRI. The aims of the BRI are multifaceted and contentious, with some commentators envisioning the BRI as a purely commercial mechanism while others argue that the BRI has geopolitical dimensions and may undermine the US's post-World 
War II global leadership. Announced in 2013 as a means to connect Eurasian markets, the BRI was later incorporated into the Constitution of the Chinese Communist Party during the 19th National Party Congress in 2017 as a method of achieving 'shared growth through discussion and collaboration' (Xinhua 2017). At present, US $\$ 4.46$ billion is earmarked for three BRI infrastructure projects in PNG: the High Priority Economic Roads Project, the Goroka Town Water Supply Upgrade Project and the PNG-China Integrated Agriculture Industrial Park.

The most significant concern raised by analysts regarding the BRI in PNG is the belief that Beijing aims to entrap partner countries in unsustainable levels of debt. Proponents of this theory argue that Beijing aims to then use this debt as leverage to achieve a combination of commercial and geopolitical aims. These purported objectives include acquiring ownership stakes in debtor countries' natural resources and infrastructure assets (which may allegedly be used for Beijing's military purposes), compelling debtor nations to support China's diplomatic initiatives (particularly as they relate to Taiwan) and transforming debtor nations into 'wholly owned subsidiaries of China' (Chefitz and Parker 2018).

However, PNG's debt-related risks are not primarily driven by Chinese lending but rather ineffective domestic policies. One of the most tangible BRI-related threats to PNG may be the exploitation of natural resources. Yet this risk is not unique to the BRI. Foreign companies from a variety of countries are also accused of exploiting PNG's natural resources. One example is the controversial Exxon-led and partly Australian Governmentfinanced PNG LNG project, which is accused of significantly decreasing economic welfare in PNG across a range of measures, including aggregate employment and household disposable income, while increasing real gross domestic product (GDP) by just 10 per cent instead of the expected 97 per cent (Jubilee 2018). While the risk of exploitation by foreign companies may be intensified by the increased investment associated with the BRI, it can only be resolved by improved domestic regulation and enforcement mechanisms regarding economic and environmental policies.

\section{The China-PNG relationship}

PNG's decision to join the BRI is a relatively natural continuation of the dynamic relationship between Port Moresby and Beijing. Though China's aid and trade presence in the Pacific are outstripped by other non-Pacific countries, China is now the region's largest bilateral lender-and PNG is 
no exception (Greenfield and Barrett 2018). In 2017, China was PNG's fourth largest export and import partner after Australia, Singapore and Japan. From China's perspective, PNG was China's second largest trading partner and largest investment destination in the Pacific (Kenneth 2017a). Though Australia's substantial aid program means that Canberra, rather than Beijing, is the main financial backer in the South Pacific, China is the Pacific's and PNG's largest bilateral creditor.

There is substantial uncertainty regarding PNG's financial reliance on China due to confusion between Chinese investment and debt in PNG as well as a lack of year-on-year official data. According to the Chinese Ambassador to PNG Xue Bing, China had invested US\$1.9 billion in PNG by the end of 2017. Media outlets such as the Asia Times and South China Morning Post have quoted this figure as representing the total volume of concessional loans PNG owes to China. Contrastingly, in 2017, PNG budgetary documents revealed that PNG's debt to China was approximately US $\$ 588$ million, comprising 23.7 per cent of PNG's total external debt (PNG Department of Treasury 2017a, 2017b). However, it is difficult to update this figure, as PNG's most recent budget refrains from identifying the total amount of debt owed to China. This omission challenges attempts to track variations in PNG's debt to China over time, an important indicator of the sustainability of PNG's debt and the overall nature of the PNG-China relationship. Moreover, in some areas of the 2020 PNG National Budget, data on PNG's debt obligations to China is grouped with PNG's debt obligations to Taiwan, rendering it difficult to track variations in PNG's debt obligations to China specifically over time (PNG Department of Treasury 2019a).

There is no universally accepted formula or debt ratio that can indicate whether foreign debt accumulation is sustainable or unsustainable (Roubini 2001). Moreover, it is not solely the volume of debt accumulation in aggregate or relative-to-GDP terms that presents risks. PNG must also be able to regularly service its debts in order to avoid defaulting on any loans. Most research outputs and media reporting on China's alleged 'debt-trap diplomacy' in the Pacific focus on the total volume of debt owed to China and the associated risks of insolvency. This close scrutiny of PNG's and PICs' total indebtedness to China may, somewhat ironically, lead observers to overlook the significant debt-servicing risks PNG faces. PNG's exposure to the risks of its volume and servicing of debt are assessed individually. 
A debt sustainability analysis by the International Monetary Fund (IMF), published in November 2017, calculated PNG's central debt-to-GDP ratio at 33.4 per cent, a relatively low figure within the domestic and regional context. This figure was already higher than the debt-to-GDP ratio of 30 per cent mandated by PNG's Fiscal Responsibility Act (IMF 2017). In October 2019, the PNG parliament reported that PNG's debt-to-GDP ratio had risen to 39.8 per cent, a figure some officials appeared to blame on the 'many, many poor investment decisions' and 'risky and often irresponsible loans' of the previous O'Neill administration (PNG Department of Treasury 2019b). A subsequent report confirmed that PNG's debt-to-GDP ratio rose to 38 per cent in 2018, which the IMF attributed to 'persistent overshoots on personnel costs, together with falling revenues' (IMF 2020). As it appeared unfeasible to lower the debt-to-GDP ratio to below the legally advised level of 30 per cent within the year, the PNG parliament agreed to raise the mandated debt-to-GDP ratio to a maximum of 45 per cent. However, the IMF projects PNG's public debt to reach 45 per cent of its GDP over the medium-term. The 2019 PNG National Budget's goal to reduce the country's debt ratio to 30 per cent of the GDP by 2022 may prove difficult to achieve in this context.

A lingering concern is whether official data captures all outstanding debt owed by the PNG Government and its various statutory authorities and state-owned enterprises (SOEs). Recent research suggests that as much as half of Chinese overseas loans to developing nations may be 'hidden' and not captured in official reporting (Horn et al. 2019). The varying transparency of both PNG and Chinese government data means that PNG's debt situation may become more ambiguous_and potentially more precarious-over time.

PNG's deteriorating debt profile led to Standard \& Poor's (S\&P) lowering PNG's sovereign credit rating from B+ to B in April 2018-five levels below 'investment grade'. The PNG Secretary for Treasury Dairi Vaele criticised the downgrade and argued that it was based on 'outdated data and failed to comprehend fully the more positive fiscal outturn in 2017 and early 2018' (PNG Department of Treasury 2018). Regardless of whether the S\&P downgrade was an accurate reflection of PNG's debt, the situation is likely to worsen unless Port Moresby implements the IMF's recommendations of consolidating its fiscal position through measures that include acquiring more cost-effective and longer-term financing. Whether China is able to offer financing that meets these requirements and partially alleviate PNG's debt situation is uncertain. 
The burden of debt-servicing repayments may present a more immediate risk to PNG. Debt servicing is persistently the government's third largest area of expenditure, comprising more than 10 per cent of total expenditure in the past three budgets. Recent estimates suggest that PNG's annual debt repayments to China will increase 25 per cent to approximately US $\$ 67$ million by 2023 (Barrett and Greenfield 2019). However, these calculations appear to draw on data from the PNG 2020 National Budget that groups China and Taiwan together as a single creditor, making it challenging to identify the proportion of the debt obligations driven by China and the proportion driven by Taiwan. Despite this limitation of the data, two insights can be drawn: China and Taiwan combined represent PNG's largest 'bilateral' creditor, and PNG's debt-servicing obligations will increase notably over the short to medium-term.

The growth of PNG's debt obligations is particularly concerning given PNG's challenges with its 'revenue crisis', which may impede Port Moresby's capacity to address outstanding debts (Howes 2017). In 2017, the PNG Government's revenue declined to 2006 levels. The 2020 budget offers hope that PNG's total revenue will reach its highest levels in the country's recorded history, but expenditure is expected to similarly rise such that PNG is left with a 'historic' budget cash deficit of K4,631.1 million (PNG Department of Treasury 2019c). The previous O'Neill administration refrained from implementing the IMF's recommendations to resolve the revenue crisis by reducing government expenditure on funds for members of parliament and depreciating the kina. However, the current Marape administration has signalled its willingness to consider an IMF bailout, heralding stricter financial measures to improve PNG's economic sustainability.

PNG's level of debt and related solvency and liquidity risks are further obscured by the lack of transparency surrounding Chinese aid. Some observers argue that Chinese aid, when disbursed as a loan, may increase the indebtedness of recipient nations (Var and Po 2017). Attaining an accurate understanding of the impact of Chinese aid on PNG's debt is particularly important, as a single Chinese project in PNG may have both aid and investment aspects, conflating the boundaries, aims and impacts of both sources of funding. One notable example is the US $\$ 1.4$ billion Ramu Nickel mine, which is among China's largest investment projects in PNG. The exact proportions of aid and commercial funding to Ramu Nickel are uncertain, and made more unclear by contradictory statements by the mine's operating company, the Metallurgical Corporation of 
China Ltd (MCC). Given Ramu Nickel's significant size and importance for both PNG and China, it is probable that BRI projects could incorporate similarly blurred boundaries between commercial finance and development aid.

According to the Lowy Institute's Pacific Aid Map, actual Chinese aid spending in PNG peaked in 2014 at approximately US\$120 million and declined to US\$22 million in 2017 (Lowy Institute 2019). However, Chinese aid spending is likely to increase in PNG over the mediumterm as the two countries implement BRI-affiliated aid projects. China's aid commitment to PNG soared to a record-high $\$ 4.7$ billion in 2017 , largely driven by the High Priority Economic Road Project. Analysing the funding composition of spent Chinese aid to PNG reveals that, in aggregate, concessional loans comprised 80.48 per cent of spent funds between 2009 and 2019. The loan composition of Chinese aid funding to PNG rose from 0 per cent in 2009 to a peak of 98.72 per cent in 2016, but then dropped year-on-year to 66.79 per cent in $2017,14.46$ per cent in 2018 and 0 per cent in 2019. In contrast, the loan composition of China's committed aid remains generally high at 99.35 per cent in 2017 , 86.87 per cent in 2018 and 0 per cent in 2019. The decline in the loan composition of China's spent aid is a significant reversal, but it is uncertain whether this trend will hold once China begins to realise its BRI-related aid commitments.

Given the burden posed by PNG's existing debts, the likelihood that joining the BRI will be accompanied by further Chinese lending, and Port Moresby's potentially limited capacity to service its debts, it is understandable that some observers are concerned about the economic risks posed by PNG's decision to join the BRI. However, China's ability to exploit this debt for political or strategic purposes is more unclear.

\section{The view from Beijing: The organisation, funding and delivery of the BRI}

Contrary to China's centralised government structure, the conceptualisation, funding and implementation of BRI projects exhibit notable decentralisation. President $\mathrm{Xi}$ and other prominent Chinese Communist Party (CCP) leaders direct top-level national strategy and rhetoric surrounding the BRI and urge Chinese government agencies to realise BRI goals. Yet there is significant scope for implementing agencies, banks and SOEs to construe Xi's direction in a way that serves 
the organisation's political or commercial interests. As these substate entities are bound by diverging mandates and interests, different institutions are likely to generate different development outcomes for BRI partner countries like PNG. Thus, recognising the variabilities between the Chinese substate organisations involved in the BRI is crucial to understanding how the BRI may function in PNG and the overarching strategic or commercial intents that drive it. Fundamentally, the impacts of the BRI in PNG are likely to be influenced not only by the combination of Chinese institutions involved but also the ability of these institutions to cooperate with relevant PNG government agencies.

Several Chinese government agencies are involved in the BRI. The National Development and Reform Commission (NDRC) and sectoral agencies appear to provide more policy input for BRI projects than the Ministry of Foreign Affairs (MFA) and Ministry of Commerce (MOFCOM) (Ye 2018). Unlike the MFA and MOFCOM, the NDRC has made several new policy proposals and risen as the central agency guiding the BRI. As the NDRC's mandate relates to domestic economic planning, this indicates that the BRI may be guided more by China's domestic needs rather than its foreign policy.

Some of the most important funding bodies for BRI projects are Chinese policy banks, Chinese commercial banks and multilateral development banks. These institutions often provide 'concessionary loans' with terms that vary widely from interest-free to commercial rates. These terms may be less favourable than funding offered by organisations like the World Bank and the ADB (Slattery et al. 2018). However, given the lack of transparency surrounding most Chinese lending agencies, it is difficult to understand the full scope of PNG's debt obligations to China or the likelihood of renegotiating onerous debt. Tonga's deferment of its US $\$ 115$ million debt to China suggests that China remains willing to provide debt relief in specific - albeit unclear-situations. Tongan officials denied speculation that China provided debt relief to Tonga in exchange for the country signing on to the BRI (which occurred five days after China provided debt deferment), but the reliability of these claims is uncertain. The modes of financing and types of lending institutions associated with the BRI generate widely different opportunities and risks for debtors, particularly small debtors like PNG that may possess limited negotiating power or leverage over China. 
The primary implementing bodies of the BRI are SOEs. Despite their linkage to the state, the motivations of individual SOEs are often a unique combination of political and commercial rationales that may be distinct from similar SOEs and the CCP itself. While Chinese private businesses in PNG abound, particularly in the retail sector, large-scale investment projects are generally driven by SOEs. Indeed, the vast majority of Chinese firms that have made investments of over US $\$ 100$ million in PNG are SOEs (Appendix 1). This trend reflects the differing preferences of Chinese SOEs and private firms, with SOEs tending to align more closely with Beijing's strategic objectives, prioritise natural resource acquisition and demonstrate neutrality to political and economic risk (Amighini et al. 2013:312-25). However, SOEs are also incentivised to 'brand' their intended projects as being part of the BRI in order to gain easier and greater access to state-backed finance (Financial Times 2017). In contrast to popular conceptualisations of the BRI as a cohesive and pre-determined strategy crafted by the CCP, the commercial motivations of SOEs may fragment the selection and implementation of BRI projects.

In addition, the practice of reverse engineering Chinese aid projects in PNG may herald further fragmentation of China's involvement in PNG and the broader Pacific (Smith 2015). This process refers to Chinese contractors and their Pacific partners developing a project and then misleadingly framing it as a local initiative to Chinese lending institutions. The complexity surrounding the implementation of the BRI generates two key implications for PNG. First, statements regarding a clear Chinese strategy in PNG may be overblown due to the diversity of interests, public agencies and private entities involved. Second, it may fall on the shoulders of PNG officials to ensure that Chinese investment projects are cohesive and work towards PNG's longer-term economic goals, rather than deliver a piecemeal and fractured result.

The complex bureaucratic processes that underlie the BRI suggest that BRI project selection may not always be rational or part of a larger overarching strategy driven by the core CCP leadership. In contrast, the number of Chinese government agencies involved, their competing interests and their unclear hierarchies are all factors that complicate the process of BRI project selection and suggest that the BRI's implementation may be more fragmented than assumed by many foreign commentators. While it is almost certain that many BRI projects are driven by Chinese foreign policy objectives, this cannot be assumed for any or all BRI projects. 
Given PNG's late entry to the BRI and the Pacific's somewhat peripheral importance to Beijing, it is unlikely that all Chinese and BRI investment in PNG are driven primarily by Beijing's geopolitical objectives.

The argument that Chinese lending in the Pacific is not driven by strategic means or debt-trap diplomacy is further supported by empirical data. Tonga is the only Pacific nation at 'high risk' of debt distress and where Chinese lending comprise the majority of debt (Fox and Dornan 2018). However, Tonga's debt to China is the result of the 2006 Nuku'alofa riots that damaged Tonga's central business district and political moves by Tongan leaders to direct loan-financed expenditures to their electorates. These loans were enabled by for-profit Chinese construction firms rather than strategic ploys or opportunism by Beijing. Fundamentally, the origins, terms and contractors of BRI projects vary widely. A multiplicity of public and private entities from China and the host country are often involved in delivering BRI projects, and each of these entities is driven by its own unique objective. Even if the CCP desired to exert debt-trap diplomacy in PNG and the Pacific, corralling the various Chinese firms and government agencies involved in the region may prove a difficult task.

\section{Is PNG selling its sovereignty?}

The dominance of the debt-trap diplomacy theory raises the questions of why PNG and other debtor nations continue to seek Chinese financing and the extent to which PNG's sovereignty is threatened by Chinese investment. While China has been accused of exploiting PNG's natural resources, projects like the Pacific Marine Industrial Zone (PMIZ) indicate that PNG companies and individuals have also gained significantly at the expense of Chinese interests. Moving beyond such zero-sum dynamics, Chinese and PNG partners have also cooperated to engineer mutually beneficial and successful development projects, such as the dormitories at the University of Goroka (Smith 2012).

While ineffective Chinese projects harm PNG's development outcomes and fiscal space, they do not dissuade PNG from continuing to seek Chinese financing. One reason for PNG's ongoing reliance on Chinese investment and aid is PNG's critical need for infrastructure development. This need may be more easily financed through China's 'flexible' and infrastructuretargeted support than Australian support, which prioritises governance initiatives (Packham 2018). The recently announced AU $\$ 2$ billion Australian Infrastructure Financing Facility for the Pacific (AIFFP) could 
see Canberra's priorities shift from governance to infrastructure, but it is currently too early to tell. The $\mathrm{ADB}$ estimates that the Pacific needs US $\$ 46$ billion in infrastructure financing over the period 2016-30. When compared to other parts of the Asia-Pacific, the Pacific Islands region has the highest proportion of investment needs as a percentage of GDP at 9.1 per cent (ADB 2017). The BRI could thus fulfil a crucial need for investment funding in PNG and its PIC neighbours if the funds are used appropriately to finance productive assets.

The focus on China's alleged debt-trap diplomacy may also overlook more tangible threats to PNG's sovereignty. Of particular concern is the fact that PNG has permitted certain concessional loan agreements, such as the agreement for the PMIZ, to be 'governed by and construed in accordance with the laws of China' rather than PNG and 'irrevocably waived any' sovereign dispute for PNG in the event of loan disputes (PNG Exposed 2012). Agreements of this nature are not always adhered to in practice. For example, a PNG court successfully ordered a block on further construction on the PMIZ in October 2012 (ABC News 2012). Yet even if these agreements are not acted upon, PNG's waiving of its sovereign immunity in certain loan disputes is concerning. This practice may carry greater risks under the more ambiguous dispute resolution mechanisms of the BRI, which are alleged to prioritise Chinese over foreign interests.

Fundamentally, while PNG's level of debt may not be ideal, any debt crises are likely to be driven more by domestic mismanagement rather than Chinese strategising. China's ability to capitalise on any debt crises in PNG is constrained by the level of fragmentation inherent in the BRI process. This fragmentation is particularly noticeable in PNG due to the practice of reverse-engineering projects, the country's late entry to the BRI and the region's lesser importance to Beijing. The focus on the debt-trap diplomacy theory of China's geopolitical ambitions may thus overlook threats that are less grand than transforming PNG into a 'tributary state', but of more immediate risk to PNG's economy and sovereignty.

\section{The economic impact of the BRI in PNG}

While the quantity of Chinese investment is rising, its quality and spread across PNG's economy are often ambiguous. Certain projects, like the University of Goroka dormitories built by Guangdong Foreign Construction (GFC), are recognised as successful Chinese projects 
(Smith 2018). Indeed, the dormitories were so favoured by locals that during the 2009 anti-Asian riots, students from the University of Goroka defended the Chinese GFC workers from rioters. In contrast, some Chinese projects, such as Lae Port and a rice monopoly project in Central Province, attract substantial criticism for overblown budgets, defective workmanship and breaches of customary landowners' rights (Eroro 2012; Papua New Guinea Today 2016). Other projects, like MCC's Ramu Nickel mine, receive both substantial criticism for environmental damages, delayed royalty payments and land ownership issues, and some praise for MCC's provision of 'schools and clinics, business opportunities and roads and bridges' (Joku 2009).

The variable quality of Chinese investment in PNG is likely due to the fact that the investing firms are often highly diverse in size, history, capabilities and organisational and operational culture-all of which influence development outcomes for PNG. However, these firms may be united in their similar levels of inexperience in PNG. As only two Chinese companies have invested in multiple projects worth over US $\$ 100$ million (Appendix 1), many large-scale investments in PNG are undertaken by Chinese firms with limited to no experience in similarly sized projects within a PNG context. Even Chinese firms with long histories in PNG may not adapt to the local context. For example, though MCC has been involved in PNG through the Ramu Nickel mine since 2005, the firm is still attempting - and struggling - to apply Chinese approaches in a PNG context (Moyle and Dayant 2018). While this inexperience does not characterise all Chinese firms in PNG, it may create challenges for future BRI projects and their Chinese contractors.

In the absence of comprehensive official data, the American Enterprise Institute and the Heritage Foundation's China Global Investment Tracker (CGIT) can be used to evaluate China's history of large-scale investment in the Pacific and identify likely BRI projects (Appendix 1). The CGIT compiles all Chinese foreign investments greater than US $\$ 100$ million in value from 2005-17. While these figures are unlikely to be precise due to the lack of official government sources, the data provides valuable insights into broad patterns of Chinese investment that are likely to be intensified under the BRI.

Chinese investments in the Pacific worth more than US $\$ 100$ million were already concentrated in PNG prior to Port Moresby signing on to the BRI. Timor-Leste and Fiji were the only other PICs that received Chinese 
investments of over US\$100 million. The limited sample size of Chinese investment in other PICs makes a cross-country comparison with PNG difficult, but it is interesting to note the role of China Railway Engineering (CRECG). CRECG was responsible for the first and largest-recorded BRI investment in Timor-Leste at US\$290 million, and is a major shareholder of China Railway Group Limited-the company that was contracted to build PNG's first three BRI projects, collectively worth US $\$ 4.46$ billion (Kenneth 2017b).

Only two Chinese companies-China Communications Construction Co., Ltd. (CCCC) and China State Construction Engineering (CSCEC) have completed multiple US $\$ 100$ million or more investments in PNG. CCCC is the only Chinese company to pursue investments of more than US $\$ 100$ million in the same sector multiple times, having invested twice in the PNG transport sector in 2012 and 2013. Out of the 15 listed Chinese investments in PNG, 60 per cent were concentrated in one of three sectors: transport (four projects), real estate (three projects) and metals (two projects). The three sectors that attracted the most Chinese investment were metals (US\$930 million), energy (US\$880 million) and real estate (US\$730 million), cumulatively making up 65 per cent of the total recorded US\$3,880 million in Chinese investment. If these trends continue under the implementation of the BRI, PNG is likely to experience an influx of investment bids from new Chinese companies targeting the energy, metals, real estate and transport sectors. The predominance of extractive and polluting industries in China's historical investment portfolio in PNG may threaten environmental sustainability and protections in PNG.

\section{PNG's environment and land tenure}

Given PICs' vulnerability to the risks of environmental degradation, pollution and climate change, the allegations that China is using the BRI to exploit foreign natural resources and outsource pollution-intensive production must be examined. Some observers argue that the BRI is partly driven by an attempt to alleviate China's oversupply of steel and cement production and will thus promote carbon- and pollution-intensive development models in host countries (Pike 2017). Indeed, rather than assisting host countries in developing renewable energy sources, the BRI may 'lock-in' their fossil-fuel dependency (Ascensão et al. 2018). China also has significant commercial interests in PNG timber, nickel and natural gas that may be expanded under the BRI. 
The PNG-China timber trade reveals that the failure by both the PNG Government and Chinese investors to exert due diligence harms the reputations of both countries and may enrich certain political and economic elites at the expense of PNG citizens. While Chinese firms are not the only foreign entities complicit in illegal logging, they deserve particular scrutiny as PNG is China's largest supplier of tropical logs and PNG exports roughly 80 per cent of its timber to China (PNG Exposed 2010). Illegal logging has been recognised as a problem in PNG since the Barnett commission in 1989. The issue recently received renewed attention due to investigations by the non-government organisation Global Witness and the controversies associated with PNG's Special Agriculture and Business Lease (SABL) licences. In 2017, major Chinese and US hardware companies were forced to halt sales and review their supply chains following a Global Witness investigation that revealed a third of PNG's timber was illegally obtained from land owned by local communities (Global Witness 2017). PNG landowners allege that the government is attempting to 'give away' local land to foreign logging companies, often originating from Malaysia, and that police personnel intimidated protestors (Pacific Media Centre 2017). These observations corroborate the Revenue Watch Institute's finding that resource governance in PNG is 'poor' due to weak government oversight, corruption and opaque data (Papua New Guinea Mine Watch 2014).

Many of these controversies occurred under the widely criticised SABLs, which saw up to 12 per cent of PNG land loaned to foreign entities for up to 99 years. Though the PNG Government claimed to have cancelled the leases following a commission of inquiry and international criticism, illegal logging has continued (Blades 2018). While much of the criticism regarding SABL licences has focused on the complicity of the Department of Lands and the PNG Forestry Authority, it is also speculated that elements of PNG customs contributed to illegal exports of timber to China. The wide variety of government agencies and officials complicit in illegal logging may complicate reforms that aim to eradicate the practice.

The SABL issue may reaffirm PNG landowners' fears that some foreign entities are attempting to alienate customary land. Certain Chinese companies are among the many foreign investors that have allegedly infringed upon landowners' rights. For example, the Basamuk Landowners Association threatened to shut down the MCC-run Basamuk refinery due to MCC's perceived neglect of local landowners and illegitimate use of the land. The association's criticism of the Madang Provincial Government's 
mismanagement of the dispute raises concerns regarding PNG officials' ability to mediate tensions between locals and foreign investors, and the credibility of government officials in the eyes of local landowners.

It must be noted that Chinese companies are not the only foreign firms to exploit PNG's environmental regulatory system. For example, Australian mining businesses and Malaysian logging entities have been implicated in significant environmental infractions in PNG. This suggests that PNG's current policy and enforcement mechanisms may be unable to prevent foreign exploitation of local resources and land.

As such, it is worth considering the BRI-related regulations that are intended to ensure Chinese investments under the BRI are legal, ethical and green to discern the extent to which PNG's natural resources are vulnerable to further exploitation. Though the Chinese Government has produced numerous policies that call for BRI projects to be environmentally friendly, such as the Guidance on Promoting Green Belt and Road, few of these policies are binding (Zhu 2015:27). Even compulsory policies possess weak enforcement mechanisms and are unevenly implemented. Enforcement mechanisms often rely on the host country reporting environmental infractions, which may be challenging in countries like PNG where accountability mechanisms may be underdeveloped, or local politicians may have stakes in Chinese projects. Despite Chinese and international rhetoric surrounding 'greening' the BRI, there may be little difference between BRI and non-BRI investments in the context of environmental risk in PNG.

\section{The ability of the BRI to destabilise PNG}

PNG's decision to join the BRI has reignited concerns that Chinese financing may prove to be a destabilising force in PNG and the Pacific. These arguments do not necessarily rely on assuming the BRI is a strategic ploy by China to control the Pacific, but rather that Chinese assistance adheres to weaker standards than other foreign development partners, contributes to corruption in PNG and threatens the security interests of traditional donors (Wallis 2017:5). This section argues that while certain Chinese investors in PNG are able to meet international standards to the point of winning competitive and lucrative $\mathrm{ADB}$ contracts, some Chinese companies and PNG officials exploit PNG's relatively weak regulatory environment for personal and commercial gains and erode good governance in the country. In addition, traditional donors like Australia view Chinese 
investment in certain PNG industries, such as telecommunications and defence, as a potential security risk and intervene accordingly. PNG may be able to exploit this competition between Australia and China to secure preferable lending arrangements. Fundamentally, joining the BRI may increase the risk of corruption in PNG if the influx in foreign lending is not accompanied by anticorruption measures and improved bureaucratic and enforcement capabilities.

\section{Adherence to international norms}

Though Chinese financing may be valued by PNG and other recipient countries for its flexibility, it has often been criticised for failing to adhere to international standards and practices, particularly in regards to transparency and accountability. While China's model of investment does not always reflect international norms, some Chinese companies in PNG play significant roles as contractors in projects funded by multilateral institutions like the ADB. This indicates that a notable proportion of Chinese work in PNG does abide by international standards and suggests that Chinese companies' cooperation with the ADB may inculcate Chinese contractors with more internationally acceptable practices.

From 2011 to 2016, the most significant contractor for ADB projects in PNG was the China Overseas Engineering Group Co. Ltd (PNG), also known as Covec (PNG) Ltd (Appendix 2). Covec is a subsidiary of China Railway Group Limited, which is in turn a subsidiary of the stateowned China Railway Engineering Corporation-the same SOE that was contracted to complete US\$4.46 billion in BRI projects in PNG.

Covec is notable not only for ranking first among the ADB's top contractors, but also for the contract amount. In the periods 2011-15 and 2012-16, Covec's ADB contract alone made up the majority of the ADB's total contract funds for PNG at 63 per cent and 56 per cent of total funding, respectively. The US $\$ 80-88$ million contracts won by Covec are also unusual, with the next highest $\mathrm{ADB}$ contract being US $\$ 14.17$ million, roughly one-sixth of this amount. Another Chinese company, Hunan Lishui Hydro and Port Co. Ltd (JV), became one of the top five most significant ADB contractors in 2012-17 by pursuing a joint venture partnership with UK company AG Investment Limited to deliver the Divune Hydropower Plant (Post-Courier 2016). Combining the contract amounts awarded to Covec and Hunan Lishui reveals that 
Chinese companies were awarded 63 per cent, 63 per cent and 26 per cent of total ADB contract funds in the 2011-15, 2012-16 and 2013-17 periods, respectively.

Though Covec has become increasingly well-established in PNG over the past decade, its history in the country is not spotless. In 2017, the PNG National Court ordered Covec to pay US\$15.5 million to Kundiawabased business man Peter Kama and his family for illegally extracting road building materials from Kama's land in 2006 (Pacific Islands Report 2017). This figure was the largest ever awarded by the National Court. Covec's history and more recent relationship with the ADB indicates that while certain Chinese companies may act dubiously, this is not always an indicator of their future behaviour. Some Chinese firms in PNG may be able to progress and deliver improved development outcomes. The cooperation between Chinese contractors and multilateral institutions like the $\mathrm{ADB}$ indicates that Chinese organisations in PNG are more diverse in terms of their operations than assumed by some commentators, which is a promising assessment for PNG's ability to ensure that the benefits of the BRI accrue proportionately and transparently to PNG.

Given the recent referendum for independence held by Bougainville, China's ties to the region are worth briefly noting, particularly as Beijing has reportedly offered valuable investments and may support Bougainville's bid for sovereignty diplomatically. Chinese representatives have approached Sam Kauona, a former Bougainville Revolutionary Army general and possible presidential candidate, with a detailed infrastructure plan that Australia and the US have reportedly not matched (Danckert and Bohane 2019). Unspecified Chinese officials also reportedly expressed interest in reopening the controversial US $\$ 58$ billion Panguna mine, which could be linked to a proposed US $\$ 1$ billion package for investment in mining, tourism and agriculture to assist Bougainville's transition to independence (Bohane 2019). However, Bougainville has experienced its own challenges with Chinese investment. Attempts to encourage Chinese investment in Bougainville from 2011 onwards resulted in joint venture Chinese-Bougainvillean companies either disappearing, failing to pay local contractors or stifling local competition. An anonymous Bougainville official claimed that the Bougainville Government 'cannot control [the Chinese companies] ... they are doing whatever they want on Bougainville' (Roka 2014). In March 2019, the Chinese partners of the Bougainville Import Export General Corporation allegedly disappeared after failing to pay taxes and 'took all the cash [out of the company] and 
left nothing' (Tseraha 2019). While it is possible that Chinese investment in Bougainville under the BRI would prove to be more organised and reliable, increased involvement by the Bougainville Government seems critical to ensuring that the mistakes of the past are not repeated.

\section{Corruption}

Chinese investment may exacerbate PNG's challenges with corruption, public sector mismanagement and poor governance by offering less regulated funding opportunities for projects of dubious development value. Most recently, former PNG prime minister Michael Somare was accused of accepting a US\$1 million bribe from Chinese company ZTE (Grigg and McKenzie 2018).

Prior to joining the BRI, the PNG Government vowed to crack down on business dealings with China by mandating local participation in Chinese projects in PNG, among other measures (Kenneth 2018). It is unclear how Port Moresby's promises will be incorporated into BRI projects. Given Port Moresby's history of awarding contracts worth hundreds of millions of dollars to Chinese companies blacklisted by the World Bank for fraud and corruption, PNG may struggle to further regulate its business dealings with China.

In 2012, PNG awarded CCCC's subsidiary China Harbour Engineering Company (CHEC) a US $\$ 290$ million contract to develop PNG's Lae Port, despite the company being blacklisted by the World Bank for fraud at the time. The PNG Government's response to CHEC's mismanagement may be more concerning than the faulty development itself. Port Moresby refrained from publicly disclosing the results of government inquiries into the Lae Port mismanagement. In addition, though a relevant PNG authority stated that CHEC would fund the repairs, then opposition leader Don Polye alleged that CHEC refused to cooperate with the PNG Government (Papua New Guinea Today 2016). Despite these controversies, the PNG Government attempted to shortlist CHEC as a contractor for the Lae Port's second phase of development prior to the announcement of the tender process. This alleged behaviour may undermine the political will and ability of the PNG Government to further regulate Chinese business dealings in PNG. Indeed, some PNG government officials may be active participants in, rather than the passive victims of, corruption involving Chinese companies. This distinction suggests that attempts to reform governance in PNG that only target Chinese investment are unlikely to 
be successful, as this would only address one side of the problem. Greater transparency regarding investment deals is necessary to reduce the risk of corruption and improve both commercial assets for Chinese investors and development outcomes for PNG.

\section{Foreign reactions}

While Chinese investment in PNG and the broader Pacific is generally viewed with suspicion in foreign policy circles, certain BRI projects are likely to be more controversial than others and may influence PICs' relationships with other countries. The BRI incorporates technology, information and communication projects that, if pursued in PNG or other PICs, may spark security concerns from nations like Australia. For example, Australia intervened to majority fund a US\$136 million cable project to PNG and Solomon Islands, planned to be developed by Huawei, due to Canberra's suspicions regarding Huawei's links to the Chinese Government. Canberra controversially announced that it would fund the US $\$ 136$ million project through the aid budget, which critics argued could reorient Australia's aid spending away from its traditional priorities of governance and towards infrastructure (Graue 2018; SBS News 2018).

While the Australian Aid Budget Summary 2018-19 does not disclose how the cable project will be funded, infrastructure spending as a percentage of overall official development assistance by investment priority was higher than the Pacific average of 21.7 per cent in both Solomon Islands (42.6 per cent) and PNG (22.5 per cent) (Australian Government 2018). Australia's promise that it will 'compete' with China's infrastructure spending in the Pacific and the establishment of the AIFFP indicate that similar episodes of competition over infrastructure projects in the Pacific_-and in PNG in particular—are likely to reignite (Wroe 2018).

PNG may be able to capitalise on this competition to attain more preferable lending arrangements, but whether this would deliver better outcomes for the PNG economy as a whole or solely for certain PNG officials is unclear. On one hand, PNG appeared to benefit from regional competition by securing a US\$300 million loan from Australia that 'replaces' a similar loan proposed by the China Development Bank in late 2019, despite claims by the Australian Government that the loan was 'completely unrelated' to China (Clarke 2019). On the other hand, then PNG prime minister Peter O'Neill is accused of using China's and 
Australia's regional rivalry to fund the construction of the controversial Western Pacific University in O'Neill's own electorate of Ialibu, Southern Highlands (PNGi 2018). O'Neill's electorate was selected as the location for the new university without any public feasibility study or independent valuation of the land. As PNG's existing universities are in need of funding and repair, the economic benefit the new university may generate is not guaranteed. If the Western Pacific University is indicative of an emerging trend in PNG development, the competition between Australia and China could worsen, rather than improve, economic outcomes in PNG.

It is highly likely that PNG's decision to join the BRI will herald more infrastructure projects that are concerning to traditional partners like Australia, which views the Pacific as its 'part of the world' (The Australian 2018). Hence, Chinese investment in PNG does not only affect the behaviour of Chinese and PNG stakeholders, but also the behaviour of other countries with strategic stakes in the Pacific. The Pacific could stand to gain from the increased foreign attention and investment from China and potential competitors that come with the BRI, but this depends on the ability of PICs' governments to manage these funds appropriately. Without greater transparency and stronger anticorruption measuresboth challenging endeavours in their own right—Port Moresby may find it difficult to ensure that BRI projects are sustainable, non-fraudulent and benefit the local and national economies.

\section{Conclusion}

Like its Pacific neighbours, PNG is in significant need of infrastructure financing that the BRI could provide. However, the BRI presents a myriad of risks to PNG's economy and governance that may have been overlooked by the current discourse, which tends to focus on the debt-trap diplomacy theory. The ability of PNG to harness the potential development benefits associated with the BRI will depend on the quality of the Chinese contractors involved and the aptitude of the responsible PNG officials. Attempts by traditional donors like Australia to dissuade PNG from relying on China are unlikely to be successful and may entrench the commonly held perception by PNG locals and leaders alike that Australia is a paternalistic force in the region. Accordingly, foreign critics of PICs' debt to China are often met with significant criticism from Pacific leaders, particularly when these critics do not offer alternative 
funding arrangements. The nascent AIFFP may mitigate these criticisms if Canberra is able to provide more cost-effective loans and fund higherquality projects than the BRI. The exact impact of the AIFFP is difficult to predict given the lack of clarity regarding the proportion of grants to loans offered, the allotment of financing across the Pacific, the sources of the AIFFP's funds and whether the AIFFP will affect Australia's aid budget for the Pacific.

Current criticisms of China's increased involvement in the Pacific and PNG's decision to join the BRI in particular tend to focus solely on the level of debt owed by PICs to Beijing. In certain cases, such as Tonga, the country's level of debt is likely to be a genuine threat to its economy and, potentially, its sovereignty. The situations of other PICs with relatively lower levels of debt, larger economies and nuanced relations with traditional donors, such as PNG and Fiji, may be more complex. The diplomatic and development efforts of traditional donors may gain greater traction with Pacific leaders if they focus on the specific high-risk elements of PNG's decision to join the BRI that this analysis has identified, rather than solely criticising the overall level of debt. This is particularly relevant when traditional donors offer debt-financing organisations of their own, such as Australia's AIFFP.

Moreover, traditional donors like Australia, New Zealand and France are unlikely to be able to outspend all Chinese investment and aid if Beijing is truly determined to control the region. Identifying and attempting to outbid specific Chinese projects in PNG that represent perceived risks to the region may represent a more realistic and effective strategy for traditional donors concerned about China's growing influence in the Pacific. Australia's outbidding of China to become the only foreign donor for the Fijian Military Forces' Black Rock Camp and the Pacific subsea cable project are two notable examples. Such reactive activity should also be accompanied by improvements in traditional donors' own aid and investment activities in the region, as this engagement is not without its flaws. As observed by a local leader in PNG, like all traditional donors to the Pacific, 'Australia needs to recognise reality: China is rising' (Clarke et al. 2018). Traditional donors like Australia may not be able to stop China's rise-and would incur backlash from Pacific leaders by attempting to do so-but they can prioritise efforts to ensure that Chinese influence in the Pacific leads to improved development outcomes, rather than debt dependency or destabilisation. 


\section{References}

ABC News 2012. PNG Court Halts Controversial Industrial Project. 24 October. www.abc.net.au/news/2012-10-24/an-png27s-tmiz-put-on-hold/4332016

ADB (Asian Development Bank) 2017. Meeting Asia's Infrastructure Needs. Manila: ADB.

Amighini, A.A., R. Rabellotti and M. Sanfilippo 2013. Do Chinese State-Owned and Private Enterprises Differ in Their Internationalization Strategies? China Economic Review 27:312-25. doi.org/10.1016/j.chieco.2013.02.003

Ascensão, F., L. Fahrig, A.P. Clevenger, R.T. Corlett, J. AG Jaeger, W.F. Laurance and H.M. Pereira 2018. Environmental Challenges for the Belt and Road Initiative. Nature Sustainability 1(5): 206-09. doi.org/10.1038/s41893-0180059-3

Australian Government 2017. 2017 Foreign Policy White Paper. Canberra: Commonwealth of Australia.

Australian Government 2018. Australian Aid Budget Summary 2018-19. Canberra: Department of Foreign Affairs and Trade.

Barrett, J. and C. Greenfield 2019. Papua New Guinea faces cash crunch as China repayment schedule ramps up. Reuters. 29 November. www.reuters.com/article/ us-papua-china-debt-idUSKBN1Y30B9

Blades, J. 2018. Loggers Still Operating on PNG Lease Despite Court Ruling. Radio New Zealand, 23 February. www.rnz.co.nz/international/pacific-news/ 351026/loggers-still-operating-on-png-lease-despite-court-ruling

Bohane, B. 2019. 'Where Is Australia?' China Makes a Bold Play for the South Pacific's 'Treasure Islands'. The Sydney Morning Herald, 17 November. www. smh.com.au/world/oceania/where-is-australia-china-makes-a-bold-play-forthe-south-pacific-s-treasure-islands-20191115-p53b4g.html

Chefitz, G. and S. Parker 2018. China's Debtbook Diplomacy: How China is Turning Bad Loans into Strategic Investments. Harvard Kennedy School Policy Analysis Exercise. Cambridge: Belfer Center for Science and International Affairs, President and Fellows of Harvard College.

Clarke, M. 2019. Papua New Guinea Budget Reveals Canberra is Spending $\$ 440 \mathrm{~m}$ to Keep China at Bay. $A B C$ News, 30 November. www.abc.net.au/ news/2019-11-29/png-budgets-reveals-canberra-spending-440million-keepchina-away/11751110 
Clarke, M., C. Pan and S. Wilson 2018. Ceding Influence? Consequences of Reducing Australian Aid in the Pacific. Submission to Parliamentary Inquiry into Australia’s Aid Program.

Danckert, S. and B. Bohane 2019. This Derelict Mine Caused a Bloody War. Now Aussie Companies are Fighting over It Again. The Sydney Morning Herald, 15 November.

Eroro, S. 2012. Ex-Customs Chief Against Rice Monopoly Project. PNG Exposed, 18 January. pngexposed.wordpress.com/2012/01/18/ex-customs-chief-againstrice-monopoly-project/

Financial Times 2017. Australia Port Project Highlights Schism over Chinese Investment. 17 July. www.ft.com/content/b4d35440-5a68-11e7-9bc8-8055 f264aa8b

Fox, R. and M. Dornan 2018. China in the Pacific: Is China Engaged in 'DebtTrap Diplomacy’? Devpolicy Blog, 8 November. devpolicy.org/is-china-engagedin-debt-trap-diplomacy-20181108/

Global Witness 2017. Stained Trade. Washington DC and London: Global Witness.

Graue, C. 2018. Budget 2018: Australia to Pay for New High-Speed Internet Cable for PNG and Solomons Using Aid Funds. ABC News, 6 May. www. abc.net.au/news/2018-05-06/budget-how-is-australia-going-to-pay-for-thepng-undersea-cable/9727192

Greenfield, C. and J. Barrett 2018. Payment Due: Pacific Islands in the Red as Debts to China Mount. Reuters, 31 July. www.reuters.com/article/uspacific-debt-china-insight/payment-due-pacific-islands-in-the-red-as-debtsto-china-mount-idUSKBN1KK2J4

Grigg, A. and N. McKenzie 2018. Chinese Aid Funded Alleged \$1 million Bribe to Former PNG Leader, Somare. The Sydney Morning Herald, 3 June. www.afr.com/world/asia/chinese-aid-funded-1-million-bribe-to-former-pngleader-somare-20180603-h10we3

Hong, C.-S. and O. Johnson 2018. Mapping Potential Climate and Development Impacts of China's Belt and Road Initiative: A Participatory Approach. SEI Discussion Brief Oct. 2018. Stockholm: Stockholm Environmental Institute.

Horn, S., C. Reinhart and C. Trebesch 2019. China's Overseas Lending. Kiel Working Paper no. 2132. Kiel: Kiel Institute for the World Economy, 4-14. doi.org/10.3386/w26050

Howes, S. 2017. Papua New Guinea 2018 Budget Fails to Solve Revenue Crisis. Devpolicy Blog, 29 November. devpolicy.org/png-budget-20171129/ 
IMF (International Monetary Fund) 2017. Papua New Guinea: Debt Sustainability Analysis. Washington DC: IMF.

IMF (International Monetary Fund) 2020. Papua New Guinea. IMF Country Report No. 20/95. www.imf.org/en/Publications/CR/Issues/2020/04/06/ Papua-New-Guinea-2019-Article-IV-Consultation-and-Request-for-StaffMonitored-Program-Press-49307

Joku, H. 2009. Landowners Urge Ramu MCC to Work. Post-Courier, 25 May.

Jubilee Australia 2018. On Shaky Ground: PNG LNG and the consequences of development failure. Sydney: Jubilee Australia Research Centre. www.jubilee australia.org/storage/app/uploads/public/5fb/8c6/2dd/5fb8c62dd $31 \mathrm{~d}$ 4510474121.pdf

Kehoe, J. 2018. US Report: China 'Debt Trap' on Australia's Doorstep. The Australian Financial Review, 13 May. www.afr.com/world/us-secret-reportchina-debt-trap-on-australias-doorstep-20180513-h0zzwd

Kenneth, G. 2017a. China’s Investment in PNG at \$US1.9B. Post-Courier, 3 October.

Kenneth, G. 2017b. Multi-Billion Kina Deal Signed to Strengthen PNG and China Relations. Post-Courier, 21 November.

Kenneth, G. 2018. Govt to Tighten Up on Dealings with Chinese. Post-Courier, 7 February.

Lowy Institute 2019. Pacific Aid Map. pacificaidmap.lowyinstitute.org/

Moyle, E. and A. Dayant 2018. Reconciling with China in the Pacific. The Interpreter, 15 October. Lowy Institute. www.lowyinstitute.org/theinterpreter/reconciling-china-pacific

Pacific Islands Report 2017. PNG Court Orders Chinese Company to Pay \$15.5 Million for Illegally Extracting Road Building Materials. 16 January.

Pacific Media Centre 2017. US, Chinese Companies Linked to PNG Land Theft, Deforestation, Says Report. Asia Pacific Report, 4 August.

Packham, B. 2018. China's More Flexible Support Better Than Australia's, Says PNG. The Australian, 12 June.

Papua New Guinea Mine Watch 2014. Revenue Watch Institute Says PNG Resource Government 'Poor'. 27 January.

Papua New Guinea Today 2016. Chinese Company's Harbour Work Done at Lae Basin is Defective: Opposition. 27 February. 
Pike, L. 2017. Explainer: Will China’s New Silk Road Be Green? China Dialogue, 11 May.

PNG Department of Treasury 2017a. 2018 Budget Estimates of Revenue and Expenditure for Statutory Authorities, Provincial Governments, Debt Services and Trust Accounts.

PNG Department Treasury 2017b. 2018 National Budget: Economic and Development Policies.

PNG Department of Treasury 2018. S\&P Global Rating for PNG. Press Release.

PNG Department of Treasury 2019a. 2020 Budget Estimates for Statutory Authorities, Provincial Governments, Debt Services and Trust Accounts.

PNG Department of Treasury 2019b. Amendments to the Fiscal Responsibility Act 2019.

PNG Department of Treasury 2019c. 2020 Budget: Take Back PNG.

PNG Exposed 2010. China Has Big Plans in PNG. 14 September. pngexposed. wordpress.com/2010/09/14/china-has-big-plans-in-png/

PNG Exposed 2012. O’Neill Allowing China to Cash in on PNG Resourcesand Making Us Foot the Bill! 26 September. pngexposed.wordpress.com/ 2012/09/26/oneill-allowing-china-to-cash-in-on-png-resources-and-makingus-foot-the-bill/

PNGi 2018. China and Australia Encouraged to Pork Barrel in Prime Minister's Backyard. 14 May. pngicentral.org/reports/china-and-australia-encouragedto-pork-barrel-in-prime-ministers-backyard

Post-Courier 2016. Construction of New Hydro Plant to Start. 24 August.

Pryke, J. 2017. No Course Correction in PNG Budget. The Interpreter, 30 November. Lowy Institute. www.lowyinstitute.org/the-interpreter/nocourse-correction-png-budget

Rajah, R., A. Dayant and J. Pryke 2019. Ocean of Debt? Belt and Road and Debt Diplomacy in the Pacific. Analysis. Sydney: Lowy Institute, 16-20.

Roka, L.F. 2014. Bougainville China Corporation is a Disaster for Bougainville. PNG Attitude, 9 December. asopa.typepad.com/asopa_people/2014/12/ bougainville-china-corporation-is-a-disaster-for-bougainville.html

Roubini, N. 2001. Debt Sustainability: How to Assess Whether a Country is Insolvent. New York: Stern School of Business, New York University.

SBS News 2018. Contract Signed for Pacific Data Cables. 19 June. www.sbs. com.au/news/contract-signed-for-pacific-data-cables 
Slattery, D., M. Dornan and J. Lee 2018. Road Management in Papua New Guinea: An Evaluation of a Decade of Australian Support. Canberra: Australian Government Department of Foreign Affairs and Trade.

Smith, G. 2012. Are Chinese Soft Loans Always a Bad Thing? The Interpreter, 29 March. Lowy Institute. archive.lowyinstitute.org/the-interpreter/arechinese-soft-loans-always-bad-thing

Smith, G. 2015. The Six Billion Kina Answer. Devpolicy Blog, 8 October. dpa.bell school.anu.edu.au/experts-publications/publications/4110/six-billion-kinaanswer

Smith, G. 2018. The Belt and Road to Nowhere: China's Incoherent Aid in Papua New Guinea. The Interpreter, 23 February. Lowy Institute. www.lowyinstitute. org/the-interpreter/belt-and-road-nowhere-china-s-incoherent-aid-papuanew-guinea

The Australian 2018. Julie Bishop's Message for China: Pacific is Australia's Patch. 5 June.

Tseraha, P. 2019. Bougainville Govt Takes Back Chinese Company. Post-Courier, 1 March.

Var, V. and S. Po 2017. Cambodia, Sri Lanka and the China Debt Trap. East Asia Forum, 18 March. www.eastasiaforum.org/2017/03/18/cambodia-sri-lankaand-the-china-debt-trap/

Wallis, J. 2012. The Dragon in Our Backyard: The Strategic Consequences of China's Increased Presence in the South Pacific. The Strategist, 30 August. Australian Strategic Policy Institute.

Wallis, J. 2017. Crowded and Complex: The Changing Geopolitics of the South Pacific. Barton: The Australian Strategic Policy Institute.

Wroe, D. 2018. Australia Will Compete with China to Save Pacific Sovereignty, Says Bishop. The Sydney Morning Herald, 18 June. www.smh.com.au/politics/ federal/australia-will-compete-with-china-to-save-pacific-sovereignty-saysbishop-20180617-p4zm1h.html

Xinhua 2017. 'Belt and Road' Incorporated into CPC Constitution. 24 October. www.xinhuanet.com/english/2017-10/24/c_136702025.htm

Ye, M. 2018. Economy in Command: Unpacking the Domestic Politics of China's Belt and Road Initiative. GEGI Working Paper 16 02/2018. Boston: Global Economic Governance Initiative, Global Development Policy Center, Boston University.

Zhu, R. 2015. Understanding China's Overseas Investments Governance and Analysis of Environmental and Social Policies. Beijing: Global Environmental Institute. 


\section{Appendices}

Appendix 1: Chinese investment over US\$100 million to the Pacific, 2005-17

\begin{tabular}{|c|c|c|c|c|c|}
\hline Year & Chinese entity & $\begin{array}{l}\text { Quantity } \\
(\$ \mathrm{~m})\end{array}$ & Sector & Subsector & Country \\
\hline 2005 & MCC & $\$ 670$ & Metals & Steel & $\begin{array}{l}\text { Papua New } \\
\text { Guinea }\end{array}$ \\
\hline 2009 & Sinohydro & $\$ 150$ & Energy & Hydro & Fiji \\
\hline 2012 & $\begin{array}{l}\text { China Communications } \\
\text { Construction }\end{array}$ & $\$ 290$ & Transport & Shipping & $\begin{array}{l}\text { Papua New } \\
\text { Guinea }\end{array}$ \\
\hline 2013 & $\begin{array}{l}\text { China Shenyang } \\
\text { International Economic } \\
\text { and Technical } \\
\text { Cooperation Corp }\end{array}$ & $\$ 100$ & Agriculture & & $\begin{array}{l}\text { Papua New } \\
\text { Guinea }\end{array}$ \\
\hline 2013 & $\begin{array}{l}\text { China Communications } \\
\text { Construction }\end{array}$ & $\$ 140$ & Transport & Autos & $\begin{array}{l}\text { Papua New } \\
\text { Guinea }\end{array}$ \\
\hline 2013 & Huawei & $\$ 200$ & Technology & Telecom & $\begin{array}{l}\text { Papua New } \\
\text { Guinea }\end{array}$ \\
\hline 2013 & Sinomach & $\$ 170$ & Transport & Autos & $\begin{array}{l}\text { Papua New } \\
\text { Guinea }\end{array}$ \\
\hline 2014 & $\begin{array}{l}\text { State Construction } \\
\text { Engineering }\end{array}$ & $\$ 250$ & Real Estate & Construction & $\begin{array}{l}\text { Papua New } \\
\text { Guinea }\end{array}$ \\
\hline 2015 & $\begin{array}{l}\text { China Railway } \\
\text { Engineering }\end{array}$ & $\$ 290$ & Transport & Autos & $\begin{array}{l}\text { Timor- } \\
\text { Leste }\end{array}$ \\
\hline 2015 & Zijin Mining & $\$ 300$ & Metals & & $\begin{array}{l}\text { Papua New } \\
\text { Guinea }\end{array}$ \\
\hline 2015 & $\begin{array}{l}\text { China Communications } \\
\text { Construction }\end{array}$ & $\$ 100$ & Transport & Autos & $\begin{array}{l}\text { Papua New } \\
\text { Guinea }\end{array}$ \\
\hline 2015 & Shandong Gaosu & $\$ 270$ & Utilities & & Timor-Leste \\
\hline 2016 & $\begin{array}{l}\text { State Construction } \\
\text { Engineering }\end{array}$ & $\$ 180$ & Utilities & & $\begin{array}{l}\text { Papua New } \\
\text { Guinea }\end{array}$ \\
\hline 2016 & Jiangsu International & $\$ 120$ & Logistics & & $\begin{array}{l}\text { Papua New } \\
\text { Guinea }\end{array}$ \\
\hline 2016 & $\begin{array}{l}\text { China Railway } \\
\text { Engineering }\end{array}$ & $\$ 130$ & Real Estate & Construction & $\begin{array}{l}\text { Papua New } \\
\text { Guinea }\end{array}$ \\
\hline 2017 & $\begin{array}{l}\text { Shenzhen Energy, Power } \\
\text { Construction Corp }\end{array}$ & $\$ 880$ & Energy & Hydro & $\begin{array}{l}\text { Papua New } \\
\text { Guinea }\end{array}$ \\
\hline 2017 & Minmetals & $\$ 350$ & Real Estate & Construction & $\begin{array}{l}\text { Papua New } \\
\text { Guinea }\end{array}$ \\
\hline
\end{tabular}

Source: American Enterprise Institute and the Heritage Foundation, www.aei.org/chinaglobal-investment-tracker/. 
Appendix 2: Top ADB contractors in PNG, 2011-17

\begin{tabular}{|c|c|c|c|c|}
\hline Year & Contractor & $\begin{array}{l}\text { Contract Amount } \\
(\$ \mathrm{~m})\end{array}$ & Rank & Sector \\
\hline 2011-2015 & Covec (PNG) Ltd & 80.27 & 1 & $\begin{array}{l}\text { Industry, Trade, } \\
\text { Transport }\end{array}$ \\
\hline 2011-2015 & Global Constructions Ltd & 14.17 & 2 & Transport \\
\hline 2011-2015 & Shorncliffe (1967) Ltd & 6.38 & 3 & Transport \\
\hline 2011-2015 & $\begin{array}{l}\text { Avenell Engineering } \\
\text { Systems Ltd }\end{array}$ & 2.98 & 4 & Health \\
\hline 2011-2015 & ARPI Ltd & 2 & 5 & Energy \\
\hline 2011-2015 & Total & 127.1 & & \\
\hline 2012-2016 & COVEC (PNG) & 88.34 & 1 & Transport \\
\hline 2012-2016 & Global Constructions Ltd & 14.07 & 2 & Transport \\
\hline 2012-2016 & Ag Investment Ltd & 11.52 & 3 & Energy \\
\hline 2012-2016 & $\begin{array}{l}\text { Hunan Lishui Hydro and } \\
\text { Port Co. Ltd (JV) }\end{array}$ & 11.52 & 3 & Energy \\
\hline 2012-2016 & Shorncliffe (PNG) Ltd & 7.7 & 5 & Transport \\
\hline 2012-2016 & Total & 158.26 & & \\
\hline 2013-2017 & Global Constructions Ltd & 14.06 & 1 & Transport \\
\hline 2013-2017 & Ag Investment Ltd & 12.44 & 2 & Energy \\
\hline 2013-2017 & $\begin{array}{l}\text { Hunan Lishui Hydro and } \\
\text { Port Co. Ltd (JV) }\end{array}$ & 12.44 & 2 & Energy \\
\hline 2013-2017 & COVEC (PNG) & 11.72 & 3 & Transport \\
\hline 2013-2017 & Shorncliffe (PNG) Ltd & 7.71 & 4 & Transport \\
\hline 2013-2017 & $\begin{array}{l}\text { Pacific Development } \\
\text { Contractors Ltd }\end{array}$ & 5.16 & 5 & Health \\
\hline 2013-2017 & Total & 91.95 & & \\
\hline
\end{tabular}

Source: Asian Development Bank, www.adb.org/publications/series/fact-sheets. 
This text is taken from The China Alternative: Changing Regional Order in the Pacific Islands, edited by Graeme Smith and Terence Wesley-Smith, published 2021 by ANU Press, The Australian National University, Canberra, Australia.

doi.org/10.22459/CA.2021.13 